\title{
Using Board Games as Anti-Corruption and Integrity Learning Media
}

\begin{tabular}{ccc}
\hline Sandri Justiana & Roto Priyono & Eko Nugroho \\
Anti-Corruption Learning Center & Deutsche Gesellschaft für Internationale & Kummara \\
Komisi Pemberantasan Korupsi (KPK) & Zusammenarbeit (GIZ) GmbH & Jakarta, Indonesia \\
Jakarta, Indonesia & Jakarta, Indonesia & eko.nugroho@kummara.com \\
Sandri.Justiana@kpk.go.id & roto.priyono@giz.de &
\end{tabular}

\begin{abstract}
One of the corruption eradication mandates assigned to the Corruption Eradication Commission (KPK) is to carry out anti-corruption education at each level of education, carry out anti-corruption public campaigns, and promote corruption eradication programmes (Law No 30/2001 on the Corruption Eradication Commission). To make anti-corruption education more effective, alternative media need to be developed that are more interesting and fun but do not detract from the essence and objectives of the learning itself. The KPK developed eight more anti-corruption and integrity board games for a wider audience, including young children, young people, students, educators, business people, and politicians. Board games are an interactive anti-corruption learning media that offer a unique way of looking at something, promote open communication, and challenge the players to work together to achieve results. Board games can be used an alternative learning media to instil anticorruption values from a young age, and as a media for public anti-corruption promotion and campaign
\end{abstract}

Keywords-anti-corruption; education; learning media

\section{BACKGROUND}

One of the corruption eradication mandates assigned to the Corruption Eradication Commission (KPK) is to carry out anti-corruption education at each level of education, carry out anti-corruption public campaigns, and promote corruption eradication programmes (Law No 30/2001 on the Corruption Eradication Commission) [1]

Through its Directorate of Public Education and Services, the KPK implements these tasks through various public activities, including learning, promotion and campaign. Methods used are story-telling and simulation. Media used include books and films. To make anti-corruption education more effective, alternative media need to be developed that are more interesting and fun but do not detract from the essence and objectives of the learning itself.

In 2014, the KPK began developing board games as anticorruption and integrity learning media. Board games were chosen to be adapted to developments in information and technology to facilitate communication of anti-corruption messages. Board games are also believed to have significant potential to promote positive changes that could be used as anti-corruption education and campaign media [2].
This game media has many benefits particularly in terms of learning activities, including stimulating thought and creativity, the ability to develop strategies, and concentration on completing a task, making learners more active, sociable and communicative, and encouraging mutual respect, sociability and honesty. [3]

Learning using board games is also sustainable campaign media that opens up space for discussion, as well as motivating people to execute their role to participate in and drive change to achieve expected impacts.

For the initial piloting, integrity material for children aged 9-12 years was developed from the animated film "Sahabat Pemberani". After a process of discussion and consultation, the KPK managed to develop a board game called "Permainan Kejujuran: Sahabat Pemberani". This board game was developed specifically to educate children about the value of integrity. This value is simulated in the game through four characters - Panji, Krishna, Kirana and Kumbi - who have to collaborate to help their neighbours get back property stolen by an evil robot. The four characters also have to stop the robot from stealing from their neighbours again.

The trials of this board game have had positive results. In general, the results of the pilot show that in general, the Sahabat Pemberani board game effectively encouraged interaction, stimulated interest in the content, and was very well liked by the participants.

In 2015, a digital version of the board game was developed. The principles of the gameplay are the same, but children can play the game on a gadget, laptop or computer. Although the game is digital, children are still encouraged to collaborate. The digital version of the Sahabat Pemberani board game is available for free download on Google Play at http://bit.ly/1nBqM1p for Android smartphones and at http://acch.kpk.go.id/games for laptops and computers. To complement the conventional version of the board game of the same name, an All Fours version was also developed.

\section{DEVElopMENT OF ANTI-CORRUPTION BOARD GAMES}

Following on from the positive outcome of the Sahabat Pemberani board game, in 2016, the KPK developed eight more anti-corruption and integrity board games for a wider 
audience, including young children, young people, students, educators, business people, and politicians.

\section{A. Keranjang Bolong, Anti-Corruption Board Game for Young Children}

Keranjang Bolong is a board game featuring four characters from Dunia Kumbinesia. The game can be played by 4 children using four pieces. As well as the four pieces, the game includes a board, dice, and cards with pictures of food, which are their supplies.

In the story, the four characters are going away together. On their way, they realize that their supplies are running out, because their basket has a hole in it. This is where the players come in. They have to replenish their supplies by moving their characters using the dice. Each square contains the kinds of food they have to collect. The winner is the person who collects all the food they need first.

\section{B. Terajana, Anti-Corruption Board Game for Children and Teens}

Terajana is an abbreviation for Tebak Rahasia Kata Jujur dan Bermakna. So it is easy to guess that the game Terajana is essentially a test of knowledge. The players are adventurers/archaeologists whose task is to find and work out the meaning of words on ancient artifacts. Along the way, the players also have to decipher ancient manuscripts that contain questions and challenges, while taking care to avoid super traps.

The players take turns to roll the dice to determine who many steps they take on the game board. The squares on the board might contain a question, encryption, or challenge. Players win points for answering questions or completing challenges. Players can also lose points for giving the wrong answer or for landing on a square that is occupied by another player. The game ends when one player gets to the finish and wins bonus points. The player with the most points wins the games.

\section{PDKT, Anti-Corruption Board Game for Teens}

In this game, the players are school pupils who play mission cards that replicate routine activities at school. Players win stars for successfully completing missions. The aim of the game is to collect as many stars as possible.

There are two kinds of mission cards: positive and negative. Players can find out if the mission is positive or negative by finding out information. To complete missions, the player recruits other players to join in the mission. Players try to get other players help them with their mission (without revealing what their mission is). The other players then hand over "Yes" or "No" cards face down to say whether they will participate in the mission. The mission is success if the quota (number of players joining in the mission) for the mission is met. Stars are won/lost depending on the mission undertaken. Players win stars for joining in and successfully completing a positive mission, and players who do not join in lose stars. Conversely, players lose stars for joining in a negative mission, and the players who do not join in win stars.

\section{D'Hospital, Anti-Corruption Board Game for Health Students and Practitioners}

The D'Hospital board game is all about good management of hospital facilities. The players compete to win the most points by collecting sets of facility cards (symbolizing control of a hospital facility). There are positive and negative facility cards. A player who collects a set of facility cards gets extra points. This game is a test of the players' decision making: they have to decide whether to take a negative card to collect a full set (to get bonus points). Each round, an event card will appear. Some of these are inspection cards, which will make things difficult for players who are holding negative facility cards. The game ends after the 10th round or when 10 event cards have been played.

\section{E. It's My Business, Business Theme Anti-Corruption Board Game}

In this game, the players are business people who are trying to win government projects. The player who has the most income wins the game. Each player has four attitude cards: Integrity, Backhander, Bribe, and Third Party. Each round, the players choose two project cards to win. Each turn, the players place an attitude card beside the project card they want. The players then get income from the project depending on the attitude card they played. The Integrity card gets the final share and the Bribe card is first in line when it comes to sharing the profits. The player who goes first gets a larger nominal amount than the player who goes last. However, there is penalty for playing the Bribe card: although the player gets money from the state, it is taken away and placed in the "State Loss" box. An event card could mean the player losing all the assets they have won if they played a Bribe or Backhander card. Although this is a competitive game, all the players lose if the amount of money in the "State Loss" box is greater than the amount of money in circulation.

\section{F. PoliTrik, Political Theme Anti-Corruption Board Game}

PoliTrik is a card game about competing for power in a political party. The game has two winners: the player who holds the Leader card and the player who holds the Secretary General card at the end of the game.

Before starting, the players deal out the position and character (personal qualities and values of the character) cards. Each turn, a player rolls the dice and gets the number of cards indicated by the dice $(1,1,2,2,3,3$ sided-dice). The player can take a combination of Power cards (used to win positions from other players) and Action cards. The player can then try to play his or her Power card to win the position of another player. If the player has a poor quality (card) character, competition for his or her position can increase. The game ends when all the Power and Action cards are finished.

\section{G. Ksatria, Anti-Corruption Board game on Dealing with Acts of Corruption and Seizing the Assets of Corrupters}

Ksatria is about kingdom that is almost in ruin as a result of corruption by officials. The king holds a competition for knights to hunt down and arrest corrupters and get back the wealth and assets they have taken. 
The game play is very simple. The players have teams of 10 knights (cards), who have different degrees of investigative ability. Each round, four corrupter cards, containing their wealth and several clues, are played. The task of each player is to assign one of his or her knights to a corrupter, which each player will take turns to chase. A corrupter is caught and his assets seized if the number of knights exceeds the degree of deviousness of the corrupter. A knight who joins in rounding up the corrupter wins points. But if the degree of deviousness of the corrupter is greater than the number of investigators (knights), the assets of the corrupter cannot be seized. The winner is the player who has the most points. However, all players lose if the amount of assets not seized exceeds the amount of assets seized.

\section{H. Jaga Sekolahku, Anti-Corruption Board Game on School Governance with Integrity}

Jaga Sekolahku is a board game that portrays the schools governance with integrity, in terms of the planning, implementation and supervision of the school.

The board game is played by $3-5$ people, using Governance, Rogue Official, Integrity and Expectation cards. The players are stakeholders in a school who have to work together to manage the school with integrity. At the same time, each player has to prevent rogue officials from interfering with the management of the school. The players have to contribute, collaborate and contemplate.

The game ends when fewer than two Expectation cards are left. The number of points on the successful Expectation cards is added up and the number of failed Expectation cards deducted for each player. The players then reflect on their game play.

\section{CONCLUSION}

Board games are an interactive anti-corruption learning media that offer a unique way of looking at something, promote open communication, and challenge the players to work together to achieve results. Board games can be used an alternative learning media to instil anti-corruption values from a young age, and as a media for public anti-corruption promotion and campaign.

\section{REFERENCES}

[1] Law No 30/2001 on the Corruption Eradication Commission

[2] E. Nugroho, Potensi Boardgame Indonesia: Memotivasi Bermain Sehat untuk Semua, presentation on slideshare.com http://www. slideshare.net/kummara

[3] W. C. Negara, Pemanfaatan Board Game dan Card Game dalam Pembelajaran, http://guraru.org/guru-berbagi/pemanfaatan-board-gamedan-card-game-dalam-pembelajaran/ 